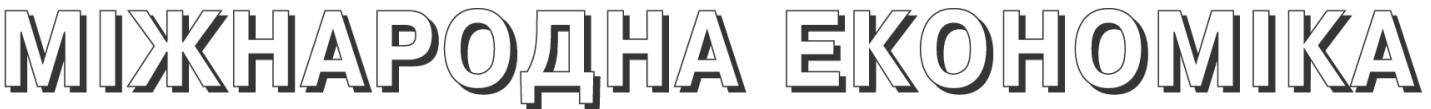

УДК 061.1€С

https://doi.org/10.31470/2306-546X-2020-45-146-151

\section{OVER 10 YEARS OF BULGARIAN MEMBERSHIP IN EU: EVALUATION OF BULGARIAN EXPERIENCE AND CONCLUSIONS ABOUT UKRAINE}

Katrandjiev Hristo, Kaniskov Vasil

Relevance of research topic. More than 10 years after Bulgaria's accession to the EU, there has been considerable «euroscepticism» among Bulgarian citizens. The study of attitudes towards Bulgarian membership in EU as well as the reasons determining these attitudes could be useful not only for Bulgaria but also for countries that are going to join the EU, including Ukraine.

Setting the task, the purpose of the study: to clarify the public attitudes (in Bulgaria) towards the Bulgarian membership in European Union and to outline useful guidelines and conclusions that could help Ukrainian representatives in the process of negotiating (for joining EU).

Method or methodology for conducting research. Stratified quota sample based on major sociodemographic attributes, face-to-face standardized interview in respondents' homes.

Results of work. The report analyzes the advantages as well as the challenges that Bulgarian people face more than 10 years later after joining European Union (EU). The analysis is based on the attitudes of Bulgarian citizens. Data is gathered by representative samples on the territory of Bulgaria. The authors try to make a logical parallel between Bulgaria and Ukraine and to formulate conclusions and practical guidelines that could help Ukraine to take better decisions in the process of negotiations for joining EU.

Conclusions according to the article. Obviously, ten years is not enough time for the Bulgaria's full integration into the EU. However, there is a very high degree of unanimity that EU-future is the most optimistic scenario for Bulgaria. The following lines outline some important reasons for possible «euroscepticism» concerning Ukraine's future EU membership: nationalist movements and parties, fundamental differences of cultural values, the different nature of academic and educational systems, the unwillingness or inability to break the language barrier, nonadaptability of Ukraine's production technologies with those of developed European countries, the striking discrepancy between types of agricultural produce, different types/technology of agricultural production, predatory use of the country's raw material base, ecological degradation, double standards of products.

Key words: European Union (EU), Bulgaria, Ukraine, membership, citizens, challenges, experience, regulations and standards, euroscepticism.

JEL Classification: F15, 052

\section{БІЛЬШЕ 10 РОКІВ ЧЛЕНСТВА В ЄС: ОЦІНКА БОЛГАРСЬКОГО ДОСВІДУ ТА ВИСНОВКИ ДЛЯ УКРАЇНИ}

Катранджієв X. I., Канісков В. Л.

Актуальність теми дослідження. Більше ніж через 10 років після вступу Болгарії до ЄС спостерігається значний «євроскептицизм» серед громадян Болгарії. Вивчення ставлення до членства 
Болгарії в ЄС, а також причин, що визначають таке ставлення, може бути корисним не тільки для Болгарії, але й для країн, які мають намір вступити до ЄС, включаючи Україну.

Постановка завдання, мети дослідження: з'ясувати ставлення громадськості (в Болгарії) до членства Болгарії в Європейському Союзі та надати корисні вказівки й висновки, які можуть допомогти українським представникам у процесі переговорів щодо вступу до ЄС.

Метод або методологія проведення досліджень. Стратифікована вибірка, що базується на основних соціально-демографічних ознаках, індивідуальне стандартизованого інтерв'ю віч-на-віч вдома у респондентів.

Результати роботи. У звіті проаналізовано переваги, а також виклики, з якими стикається болгарський народ більше ніж через 10 рік після вступу до Європейського Союзу (ЄС). Аналіз грунтується на ставленнях болгарських громадян. Дані зібрано репрезентативними вибірками на території Болгарії. Автори намагаються зробити логічну паралель між Болгарією та Україною та сорормулювати висновки та практичні вказівки, які могли б допомогти Україні прийняти більш якісні рішення у процесі переговорів щодо вступу до ЄС.

Висновки відповідно до статmі. Очевидно, що десять років - недостатній термін для повної інтеграції Болгарії в ЄС. Проте, існує дуже висока ступінь одностайності в тому, що майбутнє ЄС є найбільш оптимістичним сценарієм для Болгарії. Наступні позиції окреслюють деякі важливі причини можливого «євроскептицизму» щодо майбутнього членства України в ЄС: націоналістичні рухи і партії, фундаментальні відмінності культурних цінностей, різний характер академічної та освітньої систем, небажання або нездатність подолати мовний бар'єр, непристосованість виробничих технологій України до технологій розвинених європейських країн, разюча невідповідність між типами сільськогосподарського виробництва, різні види/технології сільськогосподарського виробництва, хижацьке використання сировинної бази країни, екологічна деградація, подвійні стандарти на продукцію.

Ключові слова: Європейський Союз (ЄС), Болгарія, Україна, членство, громадяни, виклики, досвід, регулювання та стандарти, євроскептицизм.

\section{БОЛЕЕ 10 ЛЕТ ЧЛЕНСТВА БОЛГАРИИ В ЕС: ОЦЕНКА БОЛГАРСКОГО ОПЫТА И ВЫВОДЫ ДЛЯ УКРАИНЫ}

Катранджиев Х. И., Канисков В. Л.

Актуальность темы исследования. Спустя более 10 лет после вступления Болгарии в ЕС среди болгарских граждан наблюдается значительный «евроскептицизм». Изучение отношения к членству Болгарии в EC, а также причин, определяющих это отношение, может быть полезным не только для Болгарии, но и для стран, которые собираются вступить в EC, включая Украину.

Постановка задачи, цели исследования: выявить отношение общественности (в Болгарии) к болгарскому членству в Европейском Союзе и наметить полезные рекомендации и выводы, которые могут помочь украинским представителям в процессе переговоров по вступлению в EC.

Метод или методология проведения исследования. Стратифицированная выборка, базирующаяся на основных социально-демографических характеристиках, индивидуальное стандартизированное интервью дома у респондентов.

Результаты работы. В отчете анализируются преимущества, а также проблемы, с которыми болгарский народ сталкивается более чем через 10 лет после вступления в Европейский Союз (ЕС). Анализ основан на отношении болгарских граждан. Данные собраны репрезентативными выборками на территории Болгарии. Авторы пытаются провести логическую параллель между Болгарией и Украиной и сорормулировать выводы и практические рекомендации, которые могли бы помочь Украине принять более правильные решения в процессе переговоров о вступлении в ЕС.

Выводы по статье. Очевидно, что десять лет - недостаточный срок для полной интеграции Болгарии в ЕС. Тем не менее, существует очень высокая степень единодушия в том, что будущее ЕС является наиболее оптимистичным сценарием для Болгарии. Следующие позиции обозначают некоторые важные причины возможного «евроскептицизма» в отношении будущего членства Украины в EC: националистические движения и партии, фуундаментальные различия культурных ценностей, различный характер академической и образовательной систем, нежелание или неспособность преодолеть языковой барьер, неприспособленность производственных технологий Украины к технологиям развитых европейских стран, разительное несоответствие между типами сельскохозяйственного производства, различные виды/технологии сельскохозяйственного производства, хищническое использование сырьевой базы страны, экологическая деградация, двойные стандарты на продукцию.

Ключевые слова: Европейский Союз (EC), Болгария, Украина, членство, граждане, проблемы, опыт, нормы и стандарты, евроскептицизм.

1. Introduction

Research importance. More than 10 years after Bulgaria's accession to the EU, there has been considerable «euroscepticism» among Bulgarian citizens. The study of attitudes towards Bulgarian membership in EU as well as 
the reasons determining these attitudes could be useful not only for Bulgaria but also for countries that are going to join the EU (such as Ukraine).

Research goal: The first goal of this paper is to clarify the public attitudes (in Bulgaria) towards the Bulgarian membership in European Union. The second goal is to outline useful guidelines and conclusions that could help Ukrainian representatives in the process of negotiating (for joining EU). The Bulgarian experience would be rather helpful in the Ukrainian context because of the similarities between both countries and because of the long historical, spiritual and traditional connections between the two nations (which have never been broken even for a moment). The similarities between Bulgarian and Ukrainian societies determine the relevance of similar treatment of problems connected with the adoption of any social, economic or political system.

Object of research: Bulgarian citizens living on the territory of Bulgaria, over 18 years of age.

Subject of research: Attitudes of Bulgarian citizens towards Bulgarian membership in EU.

Research methodology':

$\checkmark$ Sample model: Representative sample for the adult population of Bulgaria,

$\checkmark$ Sample size: 1021 effective interviews, education),

$\checkmark$ Sampling method: stratified quota sample based on major socio-demographic attributes (gender, age and

$\checkmark$ Data collection method: face-to-face standardized interview in respondents' homes [1].

2. Advantages of Bulgarian membership in EU from the point of view of Bulgarian citizens

After joining EU in 2007 till 2017 the evaluation of Bulgarian citizens for the EU membership is constant: approval $-53 \%$; disapproval $-16 \%$; neutral $-31 \%$. During the 10-years period, most optimistic are the young Bulgarian citizens (under 40 years of age) who are well educated, active and mobile. Most of them live in the capital Sofia and their incomes are above the average. These citizens have taken advantage of Bulgarian membership in EU.

Ten years after the joining of Bulgaria most people still perceive the EU as democratic (63\%), caring (52\%) and solidarity $(52 \%)$. In the beginning of the 10 -years period, the EU regulations and standards were perceived as imposing unfair restrictions on Bulgaria. Ten years later, however, the attitude is markedly positive: $51 \%$ of Bulgarian citizens agree that the country has benefited from the membership while $26 \%$ do not agree with that statement.

It should be pointed out that 10 years later there are some positive changes in the attitudes towards Bulgarian membership in EU:

1) Ten years later Bulgaria is economically and politically more stable compared to the years before joining $E U(40 \%)$.

2) Bulgarians citizens give a positive evaluation of the infrastructure improvement (32\%).

3) Improving access of Bulgarian producers to foreign markets (26\%).

4) European rules and standards from a source of concern (in 2007) are perceived as the advantages in 2017 (24\%).

Among the positive trends related to Bulgaria's EU membership should be mentioned the following: increased number of tourist trips, educational exchange of students, teachers and administrative staff; investments in infrastructure projects, educational programs, research; regulation of the prices of certain goods and services (for example, roaming charges) in the direction of their reduction; others.

3. Challenges ahead Bulgaria in the context of EU membership - the point of view of Bulgarian citizens

Parallel with the advantages from EU membership Bulgarian citizens, however, declare some critical evaluations. One of them is the belief that EU is bureaucratic (46\%) and inefficient $(42 \%)$. The elder citizens are more skeptical towards the Bulgarian membership compared to the younger ones.

Another important issue is the relatively low self-confidence of Bulgarian citizens. This conclusion is derived on the basis of:

1) The evaluation from a personal point of view is not as optimistic as the evaluation from the macro (the whole society) point of view: $19 \%$ of all respondents believe that their own perspectives get better while $15 \%$ perceive themselves as losers.

2) Moderate estimation of Bulgaria's efforts to achieve worthy position among European countries: $36 \%$ or respondents are convinced that Bulgaria's voice is respected by the European partners; $35 \%$ believe that Bulgaria is more significant in international trade negotiations.

3) Very important result from the survey states that $66 \%$ of Bulgarians do not feel themselves as real European citizens.

Table 1. Challenges Ahead EU: time comparison

\begin{tabular}{|l|l|l|l|l|}
\hline \multicolumn{2}{|c|}{2007} & \multicolumn{2}{c|}{2017} \\
\hline Raising competition from the side of non-EU countries & $\mathbf{4 7 \%}$ & $\begin{array}{l}\text { Raising competition from the side of non-EU } \\
\text { countries }\end{array}$ & $35 \%$ \\
\hline Energy independence & $44 \%$ & Relationships with Russia & $36 \%$ \\
\hline Common agricultural policy & $38 \%$ & Common security policy & $44 \%$ \\
\hline Common security policy & $30 \%$ & lmmigration policy & $49 \%$ \\
\hline Difficulties due to languages variability & $20 \%$ & Fight against terrorism & $63 \%$ \\
\hline
\end{tabular}

${ }^{1}$ The two waves of the research project were in done 2007 (the year of Bulgaria's accession in EU) and 2017 by the Research Agency "Alpha Research" https://alpharesearch.bg/ 
The time comparative analysis for the period 2007 - 2017 reveals a substantial dynamics of peoples' evaluations about the most important challenges ahead of Bulgaria and EU. The economic focus of perceived challenges and concerns in 2007 is replaced by the political focus in 2017 and especially security issues. As shown in Table 1 in year 2007 the major problem for Bulgarian citizens is the economic competition of countries outside EU $(47 \%)$. Ten year later, despite the raising economic growth of Asian countries, this issue disturbs considerable less people (35\%). The economic concerns are moved backwards by the more actual problems of terrorism prevention (65\%), pan-European immigration policy (growth from $15 \%$ to $49 \%$ ), common foreign and security policy (growth from $30 \%$ to $44 \%$ ), EU-Russia relations (36\%).

The perceptions of challenges concerning Bulgaria only follow the same logic - moving from the economic focus to the political one. Something else - major European problems are recognized as problems of others» but also as «ours». The biggest fears in year 2007 were connected with: (1) The invasion (import) of foreign goods (47\%); (2) Bulgarians would have unequal positions in the labor market (39\%); (3) Bulgarian specialists would emigrate abroad (37\%); (4) Foreigners will start buying Bulgarian land (37\%); (5) Bulgarian companies will face the severe competition of European companies. (Table 2).

Table 2. Challenges Ahead Bulgaria: time comparison

\begin{tabular}{|l|l|l|l|l|}
\hline \multicolumn{2}{|c|}{2007} & \multicolumn{2}{c|}{2017} \\
\hline $\begin{array}{l}\text { The invasion (import) of foreign goods and } \\
\text { bankruptcy of Bulgarian enterprises }\end{array}$ & $47 \%$ & $\begin{array}{l}\text { Worsening food quality and especially the double } \\
\text { standards }\end{array}$ & $60 \%$ \\
\hline $\begin{array}{l}\text { Bulgarians would have unequal positions in the } \\
\text { labor market }\end{array}$ & $39 \%$ & Decrease of purchasing power & $50 \%$ \\
\hline Bulgarian professionals will emigrate abroad & $37 \%$ & Human and drugs trafficking & $47 \%$ \\
\hline Foreigners will start buying Bulgarian land & $37 \%$ & $\begin{array}{l}\text { Bulgarians would have unequal positions in the } \\
\text { labor market }\end{array}$ & $46 \%$ \\
\hline $\begin{array}{l}\text { Bulgarian companies will face the severe } \\
\text { competition of European companies }\end{array}$ & $34 \%$ & $\begin{array}{l}\text { lnflux of immigrants; terrorism threats; emigration } \\
\text { of Bulgarian professionals }\end{array}$ & $44 \%$ \\
\hline
\end{tabular}

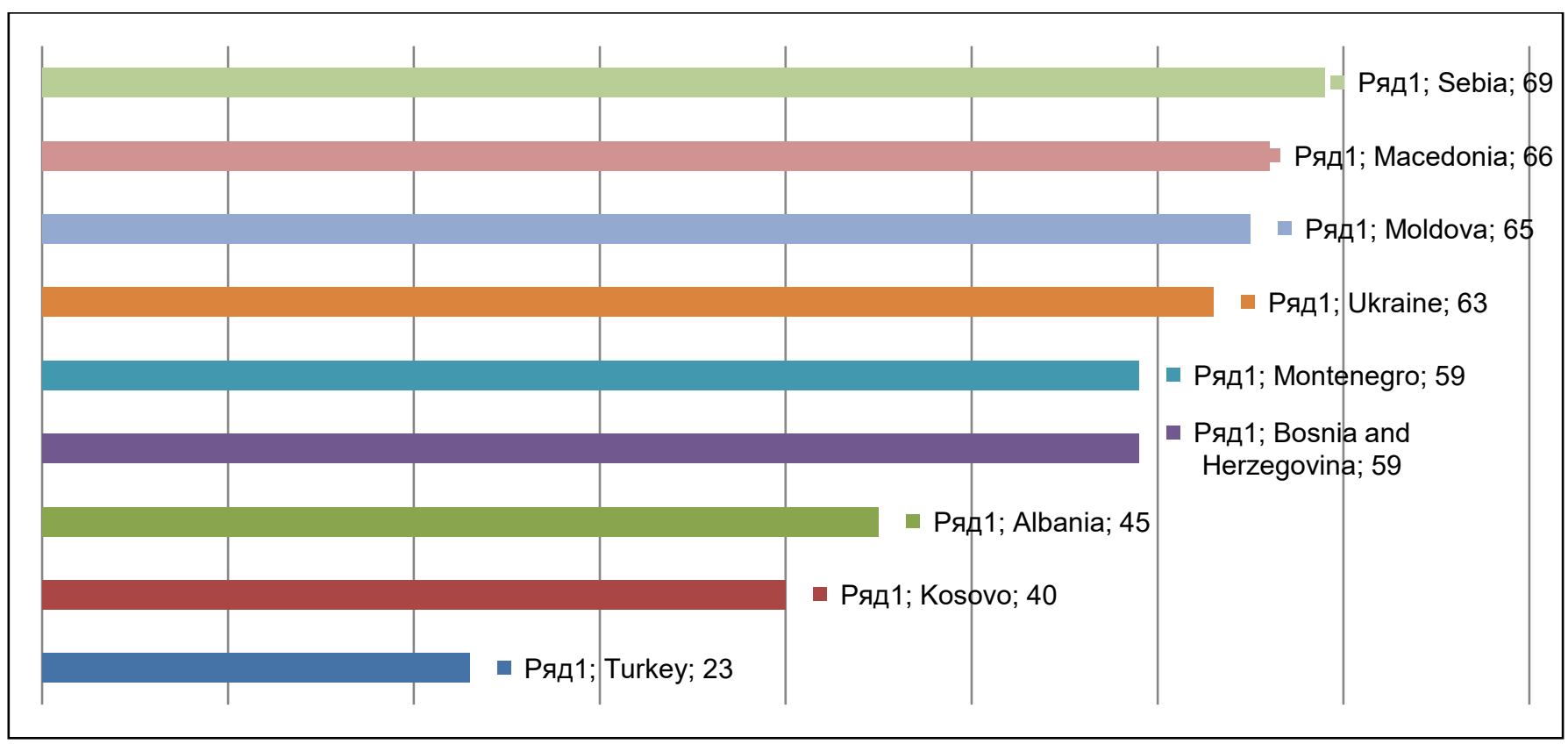

Figure 1. Support for EU enlargement, (\%)

Ten years later, some of these fears are forgotten, and the share of people who declare them is twice as low. The most serious concerns in year 2017 are: (1) Food quality and especially the double standards (60\%); (2) Decrease of purchasing power (50\%); (3) Human and drugs trafficking (47\%); (4) Bulgarians would have unequal positions in the labor market (46\%); (5) Influx of immigrants and terrorist threats (44\%).

Over $60 \%$ of Bulgarians declare their support for Serbia (69\%), Macedonia (66\%), Moldova (65\%) and Ukraine (63\%). Montenegro (50\%), Bosnia and Herzegovina (59\%) are supported by over $50 \%$ of the respondents. The support for Albania is $45 \%$ and for Kosovo $-40 \%$. The lowest score is for Turkey $-23 \%$.

\section{Bulgaria's membership in EU - conclusions for Bulgaria and guidelines for Ukraine}

Obviously, ten years is not enough time for the Bulgaria's full integration into the EU. However, the recent trends of public attitudes, the utilization of more and more membership opportunities, especially by the younger generations, show that this integration is actually happening. Moreover, it happens in a period of serious turbulence and centrifugal trends in the European Union, which inevitably affect the perceptions and evaluations of the Bulgarian 
citizens. Despite these current crises, however, there is a very high degree of unanimity that EU-future is the most optimistic scenario for Bulgaria.

What conclusions can be outlined about Ukraine's future EU membership? Following Bulgaria's experience as an EU member, some recommendations can be made to Ukraine regarding its future EU membership. The following lines outline some important reasons for possible «euroscepticism»:

1. Nationalist movements and parties whose ideologies are inherently opposed to globalization. Such movements, especially if they have widespread public support, can lead to negative attitudes among Ukrainians (who are supporters of such movement) towards EU.

2. Fundamental differences of cultural values in the field of applied and visual arts. It must be borne in mind that despite the announce of cultural diversity, the EU comes with its European values and thinking models. The clash of new European values with the original Ukrainian values and traditions may lead to a rise of Eurosceptical attitudes.

3. The different nature of academic and educational systems (Ukrainian compared to European). The Ukrainian educational and academic systems are distinctive and traditional. Exactly/precisely the Ukrainian scientists that have developed some original and new sciences lately. (For example, in the Ukrainian city Kharkov a research center «Апофеоз» [2] has been founded on October 22, 1996. The scientists in this center created the newest science (scientific field) called «Formology». This scientific field searches fundamentally new possibilities for studying all things in the universe, including man. Formology is an object of scientific interest and scientific research (including dissertations) at the National Academy of Arts - Sofia, Bulgaria. At the present moment these two places (in Ukraine and Bulgaria) are the only ones in the world that treat and analyze scientific problems on the basis of Formology) [3]. Some questions could be defined: Will the European regulations and imposed European models change the natural development of Ukrainian science? If the answer is positive, to which direction? What kind of influence on Ukrainian scientific development will be generated - positive or negative? Before joining in the EU, Ukrainian representatives might analyze these effects and have them in mind while negotiating. Otherwise, the uncritical attempt to fit into the EU's existing academic structures and thought patterns can lead to frustration and consequently Euroscepticism.

4. The unwillingness or inability to break the language barrier. Some Ukrainians may be reluctant to cross the language barrier and communicate in Western European languages (those that are official in the EU). In view of future membership, steps could be taken in order to introduce an additional official language/s in the EU.

5. Non-adaptability of Ukraine's production technologies with those of developed European countries. Ukraine's production facilities should undergo major changes in order to adapt to the EU technology base. Such changes can lead to increasing unemployment, loss of markets and other negative consequences. Differences in financial and banking policies also need to be taken into account.

6. The striking discrepancy between types of agricultural produce. Nowadays Ukraine's agricultural production is relatively clean in terms of ecology and genetic modification. Judging from the Bulgarian experience, it is likely that the production of traditional Ukrainian agriculture will be replaced by subsidized new types of agricultural crops as well as new production technologies of agricultural produce (including GMOs, hydroponics, etc.). Will this influence positively the nutritional value of the products, the health of Ukrainians, and the possibilities to export ecological foods to foreign markets, the preventing of soils, the taste of fruits and vegetables, and the ecological status quo as a whole?

7. Different types/technology of agricultural production - in EU it is intensive while in Ukraine it is land-saving. Ukrainians should appreciate the enormous advantage of their environmentally friendly and gentle way of cultivating agricultural land - something rare and increasingly valuable. After the accession of Ukraine to the EU, it is quite possible a switch to be made into intensive (even predatory) treatment of the land (which is typical for Bulgaria at the present moment). Soil-depleting agriculture combined with the shift to GMO crops will generate considerable negative effects.

8. The European Union has always shown its capitalist approach of treating natural resources (In Ukraine it will be more severe), as well as predatory use of the country's raw material base. The Ukrainian leaders and experts must do a sober analysis of the economic effects and consequences of Ukraine's EU membership. It is likely that the country's raw material base will be used by large Western producers that possess a powerful political lobbying possibilities. Bulgaria's experience in this area leads to unfavorable conclusions. One example: the state-owned nonferrous metal extraction enterprises were acquired by major Western concerns and now Bulgaria mainly exports raw materials (ore, enriched ore, concentrates, etc.), but not finished products. Concessions are long-term - in the order of 30 years. One question appears: What is the impact on Bulgarian economic development - forward or backward? And another one: What could Ukraine do to avoid such a situation?

9. Ecological degradation - many nature-polluting production processes will be transferred from Europe to Ukraine! From the point of view of Bulgarian experience one could state that polluting production processes are positioned on the territory of Bulgaria. Even more - European toxic waste is imported in Bulgaria (for processing). Within the period 2019-2020 this topic has been brought to light and seriously discussed by Bulgarian media [4]. Experts and journalists share the opinion that Bulgaria is almost about to become Europe's dump. And what awaits Ukraine in this direction? Is it likely that Ukrainian territory might become a destination for storing and processing European toxic waste (including nuclear wastes!)?

10. Double standards of products (especially foods) that are offered to the markets of Western Europe and Eastern Europe. This double standard means that the Eastern members of EU (such as Bulgaria and Ukraine) receive/will receive lower quality products compared to the Western markets. These lower quality variants of famous brands contain ingredients that are cheaper but harmful for peoples' health. 


\title{
Sources
}

1. Official site ALPHA RESEARCH. URL: https://alpharesearch.bg/

2. Official site Center for the study of psi-phenomena "Apotheosis». URL: http://www.apofeoz.org/html/ formology.html

3. Канисков, В., Формология, Изток-Запад, 2014.

4. Official site Center for the study of psi-phenomena «Apotheosis». URL: https://www.mediapool.bg/news/ find/?word =\%D1\%82\%D0\%BE\%D0\%BA\%D1\%81\%D0\%B8\%D1\%87\%D0\%BD\%D0\%B8\%20\%D0\%BE\%D1\%82\% D0\%BF\%D0\%B0\%D0\%B4\%D1\%8A\%D1\%86\%D0\%B8

\section{References}

1. Official site ALPHA RESEARCH. URL: https://alpharesearch.bg/

2. Official site Center for the study of psi-phenomena "Apotheosis». URL: http://www.apofeoz.org/html/ formology.html

3. Kaniskov, V. (2014). Formologiya [Formology], Iztok-Zapad.

4. Official site Center for the study of psi-phenomena «Apotheosis». URL: https://www.mediapool.bg/news/ find/?word =\%D1\%82\%D0\%BE\%D0\%BA\%D1\%81\%D0\%B8\%D1\%87\%D0\%BD\%D0\%B8\%20\%D0\%BE\%D1\%82\% D0\%BF\%D0\%B0\%D0\%B4\%D1\%8A\%D1\%86\%D0\%B8

\section{DATA ABOUT THE AUTHORS}

prof. dr. Hristo Ivanov Katrandjiev

University of National and World Economy, Sofia, Bulgaria

e-mail: hristokat@abv.bg

dipl. eng. dr. Vasil Liubenov Kaniskov

National Academy of Arts, Sofia Bulgaria

Sofia University «St. Kliment Ohridski», Sofia, Bulgaria

e-mail: kaniskov@mail.bg

\author{
ДАННЫЕ ОБ АВТОРАХ \\ доктор, профессор Христо Иванов Катранджиев \\ Университет национального и мирового хозяйства, София, Болгария \\ e-mail: hristokat@abv.bg \\ доктор, преподаватель Василь Любенов Канисков \\ Национальная академия искусств, София Болгария \\ Софийский университет им. Св. Климент Охридски, София, Болгария \\ e-mail: kaniskov@mail.bg
}

Подано до редакції 15.03.2020

Прийнято до друку 02.04.2020

УДК 338.47

https://doi.org/10.31470/2306-546X-2020-45-151-157

\section{МОРСЬКА ІНФРАСТРУКТУРА УКРАЇНИ У РЕЙТИНГУ КРАЇН СВІТУ: СУЧАСНИЙ СТАН ТА ПЕРСПЕКТИВИ}

Кудрицька Н. В.

Стаття присвячена проблемі визначення основних напрямів фрормування конкурентоспроможної морської інфрраструктури України, актуальність якої підтверджена у Стратегії розвитку морських портів України на період до 2038 року, Морській доктрині України на період до 2035 року.

Проблемам підвищення конкурентоспроможності морської інфрраструктури присвячено багато наукових праць зарубіжних та вітчизняних вчених. Проте слід відмітити недостатність вітчизняних праць щодо проблем розвитку морського та річкового транспорту у сучасних економічних умовах, які характеризуються зростанням процесів глобалізації та інтеграції.

Метою статті є оцінка позиції України у рейтингу країн світу за рівнем розвитку морського транспорту та визначення стратегічних заходів фрормування конкурентоспроможної національної морської інсрраструктури.

Автором наведений огляд стану та прогноз розвитку морських перевезень у світі. Сфрормульовані переваги доставки товару морським транспортом, які обумовлюють його конкурентоспроможність.

Визначені позиції України у рейтингу країн світу за кількістю суден морського торгівельного фрлоту та довжиною водних шляхів. Наведена характеристика найбільших за обсягом світових альянсів на ринку контейнерних перевезень морським транспортом.

У статті підкреслена проблема невизначеності перспектив розвитку морських перевезень, яка обумовлена поєднанням геополітичних і економічних ризиків, що пов'язано з торговельною політикою, 